\title{
Prevalence of Gingival Recession in Dental Students from the Federal University of Juiz de Fora - Brazil
}

\author{
Prevalencia de Recesión Gingival en Estudiantes de Odontología \\ de la Universidad Federal de Juiz de Fora - Brasil
}

Jessica de Souza Gama Machado ${ }^{\text {\& }}$ Márcio Eduardo Vieira Falabella²

\begin{abstract}
MACHADO, J. S. G. \& FALABELLA, M. E. V. Prevalence of gingival recession in dental students from the Federal University of Juiz de Fora - Brazil. Int. J. Odontostomat., 13(3):299-304, 2019.

ABSTRACT: Gingival recessions are characterized by partial denudation of the root surface due to apical displacement of the gingival margin from the amelocemental junction and may be localized or generalized. The aim of this study was evaluate the prevalence of gingival recession and dentine hypersensitivity of dental students of Federal University of Juiz de Fora, Brazil. Were examined 80 students with on average age of 22.9, randomly selected to assess the prevalence, level of gingival recession and the presence of dentinal hypersensitivity. Fifty students had at least one gingival recession and dentine hypersensitivity was observed in 28 students. Buccal surface was the most prevalent $(86.6 \%)$, with measures mostly between 1 and $2 \mathrm{~mm}(92 \%)$ and classified as Class I Miller (96.25\%). The pre-molars were the group most frequently affected teeth $(37.35 \%)$. Gingival recession with small measures is a very common condition in young patients.
\end{abstract}

KEY WORDS: gingival recession, prevalence, periodontics.

\section{INTRODUCTION}

Periodontal disease (PD) is characterized by an inflammatory process induced by bacterial antigens through the dental biofilm. It is a multifactorial disease and is also associated with individual's susceptibility, risk, systemic and occlusal factors (Slots, 2017).

The attachment loss caused by PD is clinically manifested by the presence of periodontal pockets and / or gingival recession (GR) (Falabella et al., 2016), which was defined as an apical position of the gingiva resulting in root exposure (Kassab \& Cohen, 2003).

The multifactorial etiology of GR is associated with local anatomical factors and triggering factors, as well as the inflammatory process induced by the accumulation of bacterial biofilms. The local anatomical factors are considered to be predisposing and are mainly related to bone dehiscences and fenestrations, thin cortical bone, marginal gingival thickness, abnormal position of the teeth in the arch, and frenulum insertion near the cervical region of gingiva (Zucchelli \& Mounssif, 2015). Among the external or triggering factors, traumatic brushing is commonly associated with the initiation and progression of localized non-inflammatory GR (Heasman et al., 2015). The other aggravating factors are non-carious cervical lesions (abrasion, abfraction, erosion, attrition and resorption), occlusal traumas, inflammation, piercing and iatrogenic factors (surgical procedures, orthodontic therapy) (MinayaSánchez et al., 2012; Nguyen-Hieu et al., 2012). Tobacco use and presence of supragingival calculus are also factors associated with the occurrence of localized and generalized GR (Müller et al., 2002; Susin et al., 2004; Chrysanthakopoulos, 2014).

The GRs were classified by Miller (1985) in Class I and II where there is no loss of support tissue in the interdental region and in Class II the recession goes beyond the mucogingival junction (MGJ). In class III the recession goes beyond the MGJ and tissue loss occurs in the interdental region and / or improper dental positioning and in Class IV the recession goes beyond the MGJ with severe loss of interdental bone and gingival tissue (Zucchelli \& Mounssif).

\footnotetext{
${ }^{1}$ Bachelor of Science in Dentistry, Federal University of Juiz de Fora, Brazil.

${ }^{2}$ Phd in Periodontics, Associate Professor in Faculty of Dentistry, Federal University of Juiz de Fora, Brazil.
} 
In addition to the unsightly appearance, the condition may result in dentin hypersensitivity $(\mathrm{DH})$, difficulty in plaque control, especially if the MGJ is reached (Minaya-Sánchez et al.; Andrade et al., 2013). The therapies used in cases of GR initially are periodontal maintenance, guidance on dental hygiene, occlusal adjustments and restorative procedures, in order to evaluate the need for surgical. Mucogingival therapy aims to increase or create a keratinized tissue and also root coverage. Several techniques are used for root coverage but the prognosis is only considered predictable and safe in the Class I and Class II recessions, while only expecting partial coverage in the Class III and Class IV recessions (Cairo et al., 2014; Milinkovic et al., 2015). Currently, the subepithelial connective tissue graft (CTG) technique associated with the coronal advanced flap (CAF) is the most used, due to the high success rate in the esthetic corrections of multiple recessions (Jepsen et al., 2013; Falabella et al.).

$\mathrm{GR}$ is a common clinical condition in the population and can be observed both in people with good or poor biofilm control, or associated with destructive periodontal disease (Susin et al.). Some researchers have reported higher frequency in men than in women (Toker \& Ozdemir, 2009; Chrysanthakopoulos, 2013; Rios et al., 2014) and many studies have reported increasing prevalence, extension, and severity with the increase of the age (Furlan et al., 2008; Sarfati et al., 2010; Rios et al.).

With all this, it is possible to verify that the GR are the reason of frequent visits to the dentist, often due to the compromised aesthetics, the dental sensitivity and carious lesions. Therefore, it is extremely important to determine the causes and choose the best treatment, since it is a condition that affects a large part of the population.

The aim of this study was to evaluate the prevalence, extent and classification of gingival recession and dentine hypersensitivity in dental Brazilian students.

\section{MATERIAL AND METHOD}

A total of 80 dental students (450 students enrolled) from the Federal University of Juiz de Fora, Brazil, randomly selected, were examined to evaluate the prevalence and levels of gingival recessions. Participants were selected according to the following inclusion criteria: age between 18 and 35 years, having at least 20 teeth and not having systemic diseases. Were excluded from the clinical exams the teeth with total crowns, fixed and removable prostheses, implants and holders of fixed orthodontic appliance. Participants signed an informed consent form, previously submitted and approved by the Research Ethics Committee of the Federal University of Juiz de Fora, No. 1.610.099.

The periodontal clinical examination was performed from June to September 2016 by a single calibrated examiner (JM) using a millimeter periodontal probe (Hu-Friedy PC PUNC $\left.n^{\circ} 15\right)$, measuring gingival recessions on the surfaces: vestibular, mesial, distal and lingual of all selected teeth. In addition, bleeding on probing and pocket depth were evaluated in order to determine the diagnosis of periodontal diseases according to the classification of periodontal diseases in periodontitis and gingivitis.

The number of teeth of each individual was recorded, the presence, location, extent and classification of recessions, whether the individuals were smokers, whether they underwent orthodontic therapy and whether dentin hypersensitivity (DH) was present. Analysis according to the scale divided into $0=$ absence of pain, $1=$ mild, $2=$ moderate and $3=$ severe pain (Garcia et al., 2009). The dentin hypersensitivity was verified by air blast with triple syringe for 2 seconds at a distance of 2 to $3 \mathrm{~mm}$ from the $\mathrm{GR}$ region.

Gingival recessions were classified according to Miller (1985) in class I when it did not reach MGJ and there is no interproximal bone and tissue loss (Fig. 1); in class II when it extends to close to the MGJ and there is no interproximal bone and tissue loss (Fig. 2); in class III when it extends to close to or reaches the MGJ, with interproximal bone or tissue loss or dental malposition (Fig. 3) and class IV when there is interproximal tissue loss and severe bone loss (Fig. 4).

Absolute and percentage distributions (descriptive statistics) were obtained for data analysis and the Spearman correlation test was used to test the association between the number of gingival recessions and the variables: sex and orthodontic therapy. The data were analyzed using the SPSS statistics 22 and differences were considered significant at $\mathrm{P}<0,05$. 


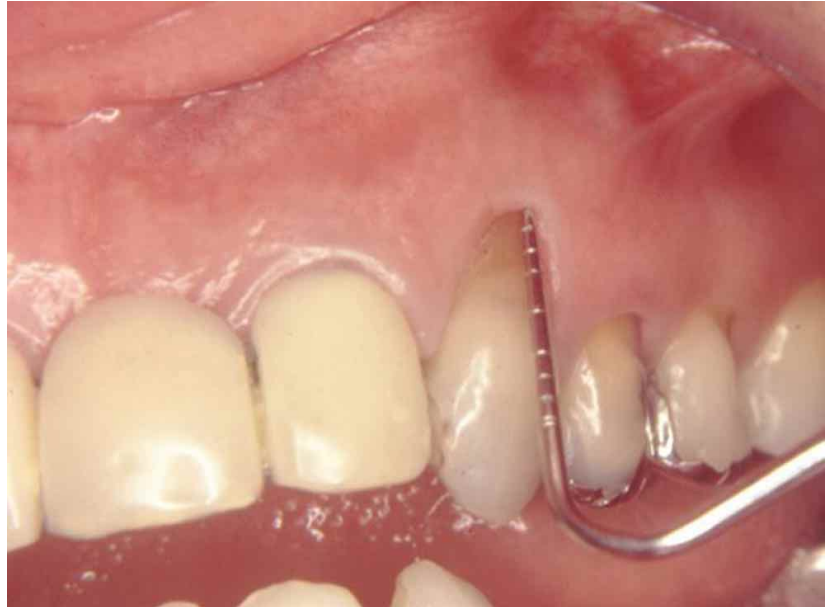

Fig. 1. Gingival recession Miller class 1.

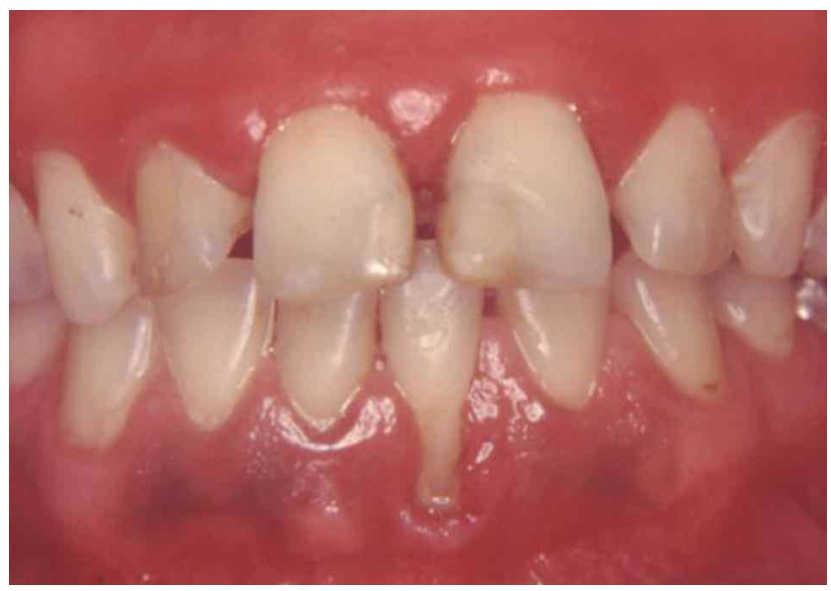

Fig. 2.Gingival recession Miller class 2.

\section{RESULTS}

The individuals evaluated were between 18 and 28 years old, mean of $22.9(S D \pm 2.08)$. The sample consisted of 80 students, 63 women $(78.75 \%)$ and 17 $(21.25 \%)$ men, and 50 students $(62.5 \%)$ had at least one tooth with GR. Smokers were $5 \%$ of the students and underwent orthodontic treatment 57 students (71.25\%). Nobody showed gingivitis or periodontitis.

A total of 2278 teeth were examined and 166 teeth presented GRs on 179 surfaces. The teeth showing the highest occurrence of GRs were the lower premolars, representing $37.35 \%$ of the total, followed by upper premolars (19.28\%) and lower incisors (16.26 $\%)$. The percentage of occurrence of recessions per tooth is described in Table I. Women showed GR in 113 surfaces and men in 66.

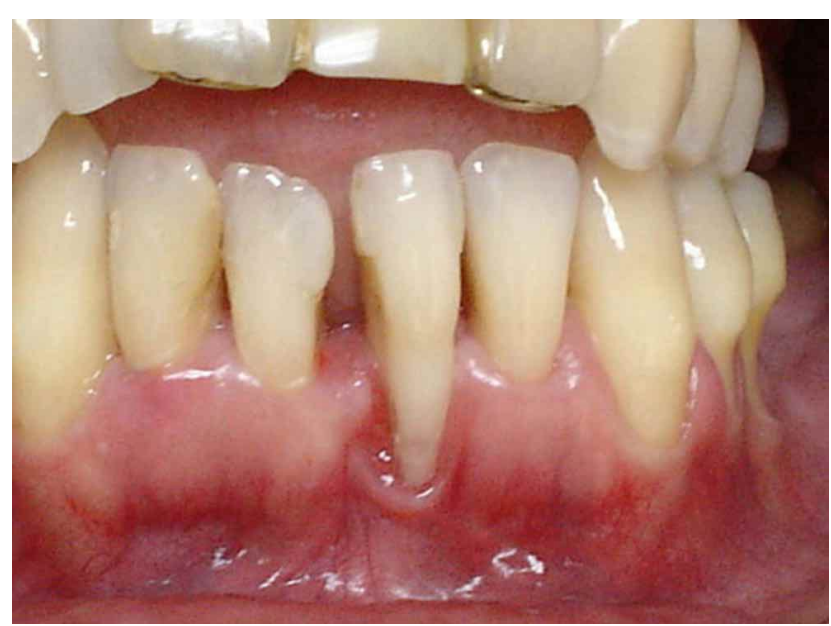

Fig. 3. Gingival recession Miller class 3

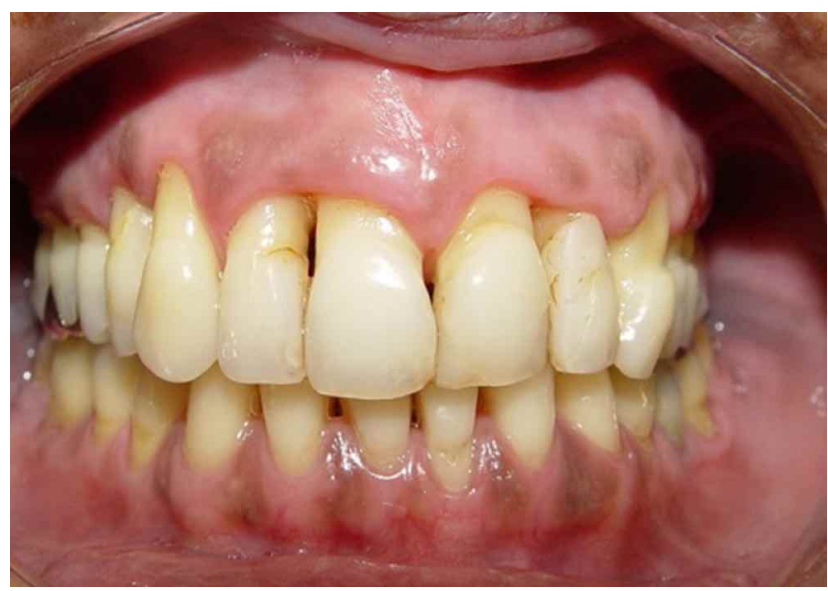

Fig. 4. Gingival recession Miller class 4.

Recessions were more frequent on the buccal surface of the examined teeth with a total of 155 (86.6 $\%)$, and lingual recessions were $24(13.4 \%)$. The distribution of recessions by surfaces and measures in millimeters is described in Table II. Only three teeth showed recessions class II of Miller (1985), all others were class I, corresponding $96.25 \%$ of the sample.

Measurements of GRs varied between 1 and 3 $\mathrm{mm}$, with a higher occurrence of 1 and $2 \mathrm{~mm}$, which represented $92 \%$ of the total. The distribution of students according to the measure of recessions is described in Table III.

Among the 50 students with GRs, 28 reported $\mathrm{DH}$, and 16 reported pain of mild intensity, 9 moderate 
and severe 3 , and all students who reported moderate or severe $\mathrm{DH}$ had a recession of $2 \mathrm{~mm}$ or more.

There was no statistical correlation between sex and the fact that individuals were submitted to orthodontic therapy and the occurrence of gingival recessions $(P>0.05)$.

Table I. Number of gingival recession $(\mathrm{N})$ and percentage (\%) per teeth group.

\begin{tabular}{lcc}
\hline \multicolumn{1}{c}{ Teeth } & $\mathrm{N}$ & $\%$ \\
\hline Upper Incisors & 0 & 0 \\
Upper Canines & 8 & 4.82 \\
Upper premolars & 32 & 19.28 \\
Upper Molars & 17 & 10.24 \\
Lower Incisors & 27 & 16.26 \\
Lower Canines & 15 & 9.04 \\
Lower premolars & 62 & 37.35 \\
Lower Molars & 5 & 3.01 \\
\multicolumn{1}{c}{ TOTAL } & 166 & 100 \\
\hline
\end{tabular}

Table II. Distribution of gingival recessions and percentage $(\%)$ by faces measured in millimeters.

\begin{tabular}{ccc}
\hline Measurement $-\mathrm{mm}$ & $\mathrm{N}$ & $\%$ \\
\hline Without recession & 30 & 37.5 \\
$1 \mathrm{~mm}$ & 11 & 13.75 \\
$2 \mathrm{~mm}$ & 35 & 43.75 \\
$3 \mathrm{~mm}$ & 4 & 5 \\
TOTAL & 80 & 100
\end{tabular}

Table III. Distribution of students according to gingival recession measures.

\begin{tabular}{lcc}
\hline \multicolumn{1}{c}{ Measurement - mm } & $\mathrm{N}$ & $\%$ \\
\hline Buccal - 1 & 86 & 38.35 \\
Buccal - 2 & 61 & 20.55 \\
Buccal - 3 & 8 & 2.74 \\
Lingual - 1 & 17 & 21.23 \\
Lingual - 2 & 7 & 13.01 \\
TOTAL & 179 & 100 \\
\hline
\end{tabular}

\section{DISCUSSION}

Gingival recession may favor the occurrence of caries and dentin hypersensitivity and therefore requires more knowledge in the diagnosis, detection of etiological factors and evolution of techniques for its therapy, as well as epidemiological studies that determine the treatment needs.
Thus, the present study examined 80 undergraduate students of the UFJF and found at least one GR in $62.5 \%$ of the sample, a similar result to the study by Chrysanthakopoulos (2014) that reported the occurrence of GR in $63.9 \%$ of individuals evaluated and Löe et al. (1992) with 60 $\%$ and Vehkalahti (1989) who found $68 \%$. However, other studies have identified higher prevalence with results above 80 \% (Marini et al., 2004; Araújo et al., 2007; Sarfati et al.; Matas et al., 2011; MinayaSánchez et al.). It is possible that this difference is because the sample has a very low average age of 22.9 years, since the GR shows an increasing rate with advancing age (Löe et al.; Susin et al.). In addition, the subjects had good periodontal health, which demonstrated good control of biofilm, which would eliminate one of the main etiological factors associated with RG, which is the inflammatory process generated by its deleterious effect (Chrysanthankopoulos, 2013).

The most affected teeth were the lower premolars $(37.35 \%)$, followed by upper premolars $(19.28 \%)$ and lower incisors (16.26\%), showing results similar to those of Furlan et al., in which lower premolars were also the most prevalent with 19.82 $\%$, and Nguyen-Hieu et al. who observed the premolars most frequently associated with GR. However, Araújo et al. and Marini et al. evaluated higher frequency of RG in the lower incisors, while Andrade et al. observed higher occurrence in the upper molars.

The buccal surface $(86.5 \%)$ was more affected than the lingual surface in this study, and Miller's class I obtained a higher prevalence, which was in agreement with most of the studies (Marini et al.; Araújo et al.; Andrade et al.). This predominance of buccal recessions is probably related to etiological factors such as incorrect brushing and due to orthodontic treatments, since $71.25 \%$ of the students underwent this therapy. The almost total occurrence of class I recessions was due to the absence of the diagnosis of periodontitis.

It was observed a higher frequency of recessions of 1 and $2 \mathrm{~mm}$ (92\%), with only 4 teeth reaching $3 \mathrm{~mm}$. According to Andrade et al., recessions of mild severity were also the most common with $81.19 \%$, Araújo et al. found $80.1 \%$ in the $2 \mathrm{~mm}$ recessions and in the study by Toker \& Ozdemir showed $17.4 \%$ in recessions of 1 to $2 \mathrm{~mm}$, also with greater predominance. This fact can be 
explained by the study population being very young, since higher levels of recession are associated with more advanced age (Susin et al.). Dentin hypersensitivity and root caries are considered as consequences of GR (Minaya-Sánchez et al.) and the $\mathrm{DH}$ is associated with erosion and inadequate brushing with excessive force (Furlan et al.; Heasman et al.). In the present study, DH was verified in 28 (35\%) students, most of whom reported sensitivity of light intensity (32\%) and only 9 and 3 students reported moderate and severe intensity, respectively. Furlan et al. found a lower frequency of $\mathrm{DH}$, with $28 \%$ of the sample. Kamal et al. (2014) observed a prevalence of $23.6 \%$ in patients with $\mathrm{GR}$, with moderate pain being the most common. Probably this low frequency of hypersensitivity is related to the fact that the recessions evaluated are small and classified as class I of Miller.

The relationship between smoking and the occurrence of GR in this study could not be evaluated because the number of smokers in the sample was very low. Müller et al. found no significant difference in prevalence between smokers and nonsmokers, however, Furlan et al. reported that smokers are at higher risk of developing HD than nonsmokers.

The prevalence of gingival recessions in young patients of more than $60 \%$, shown in this study, emphasizes the importance of its early diagnosis and the improvement of surgical therapies for its treatment, aiming at functional and aesthetic corrections.

\section{CONCLUSIONS}

1) $62.5 \%$ of the students had at least one gingival recession.

2) Lower premolars were the most affected by the recession, followed by upper premolars and lower incisors.

3) Gingival recessions were more frequent on the buccal surface, with measures more prevalent between 1 and $2 \mathrm{~mm}$ and almost all classified as Miller Class I.

4) Dental hypersensitivity was observed in 28 students, with a higher frequency of mild intensity.
MACHADO, J. S. G. \& FALABELLA, M. E. V. Prevalencia de recesión gingival en estudiantes de odontología de la Universidad Federal de Juiz de Fora - Brasil. Int. J. Odontostomat., 13(3):299-304, 2019.

RESUMEN: Las recesiones gingivales se caracterizan por una denudación parcial de la superficie radicular debido al desplazamiento apical del margen gingival, desde la unión amelocemental y puede ser localizada o generalizada. El objetivo de este estudio fue evaluar la prevalencia de la recesión gingival y la hipersensibilidad dentinaria en estudiantes de Odontología de la Universidad Federal de Juiz de Fora, Brasil. Se examinaron 80 estudiantes con una edad promedio de 22,9, seleccionados al azar para evaluar la prevalencia, el nivel de recesión gingival y la presencia de hipersensibilidad dentinal. En cincuenta estudiantes se observó al menos una recesión gingival y se reportó hipersensibilidad a la dentina en 28 estudiantes. La superficie oral fue la más prevalente $(86,6 \%)$, con medidas principalmente entre 1 y 2 mm (92\%) y clasificada como Clase I Miller $(96,25$ $\%)$. Los premolares fueron el grupo de dientes afectados con mayor frecuencia $(37,35 \%)$. La recesión gingival con medidas pequeñas es una condición muy común en pacientes jóvenes.

PALABRAS CLAVE: recesión gingival, prevalencia, periodoncia.

\section{REFERENCES}

Andrade, L. S.; Silva, B. G. N.; Palhari, F. T. L. \& Souza, D. M. Avaliação das recessões gengivais em adultos periodontalmente saudáveis. Braz. J. Periodontol., 23(1):45-50, 2013.

Araújo, A. C. S.; Jovino-Silveira, R. C.; Almeida, E. C. B.; Bello, D. M. A. \& Cavalcante, D. C. Avaliação dos níveis de recessão gengival em estudantes de odontologia da Universidade Federal de Pernambuco. R. G. O. (Porto Alegre), 55(2):139-42, 2007.

Cairo, F.; Nieri, M. \& Pagliaro, U. Efficacy of periodontal plastic surgery procedures in the treatment of localized facial gingival recessions. A systematic review. J. Clin. Periodontol., 41 Suppl. 15:S44-62, 2014.

Chrysanthakopoulos, N. A. Gingival recession: prevalence and risk indicators among young greek adults. J. Clin. Exp. Dent., 6(3):e243-9, 2014.

Chrysanthakopoulos, N. A. Prevalence and associated factors of gingival recession in Greek adults. J. Investig. Clin. Dent., 4(3):178-85, 2013.

Falabella, M. E. V.; Gonçalves, F. O.; da Silva, D. G.; Soares, L. G. $\&$ Barreto, L. P. D. Root coverage with connective tissue graft. Two case reports. Dent Cadmos, 84(3):2-6, 2016.

Furlan, L. M.; Sallum, A. W.; Sallum, E. A.; Nociti Junior, F. H.; Casati, M. Z. \& Ambrosano, G. M. B. Incidência de recessão gengival e hipersensibilidade dentinária na clínica de graduação da FOPUNICAMP. Periodontia, 18(1):64-72, 2008.

Garcia, C. H.; Kahn, S.; Galan Jr., J.; Namen, F. M. \& Machado, W. A. S. Avaliação clínica da hipersensibilidade dentinária após tratamento com dessensibilizantes comerciais. Periodontia, 19(2):78-85, 2009.

Heasman, P. A.; Holliday, R.; Bryant, A. \& Preshaw, P. M. Evidence 
for the occurrence of gingival recession and non-carious cervical lesions as a consequence of traumatic toothbrushing. J. Clin. Periodontol., 42 Suppl. 16:S237-55, 2015.

Jepsen, K.; Jepsen, S.; Zucchelli, G.; Stefanini, M.; de Sanctis, M.; Baldini, N.; Greven, B.; Heinz, B.; Wennström, J.; Cassel, B.; et al. Treatment of gingival recession defects with a coronally advanced flap and a xenogeneic collagen matrix: a multicenter randomized clinical trial. J. Clin. Periodontol., 40(1):82-9, 2013.

Kamal, H.; Hantash, R. O. A.; Taani, D. Q. \& Hammad, M. M. The prevalence of dentine hypersensitivity and gingival recession among Jordanian Patients at JUST Dental Teaching Center. Open J. Stomatol., 4(11):497-506, 2014.

Kassab, M. M. \& Cohen, R. E. The etiology and prevalence of gingival recession. J. Am. Dent. Assoc., 134(2):220-5, 2003.

Löe, H.; Anerud, A. \& Boysen, H. The natural history of periodontal disease in man: prevalence, severity, and extent of gingival recession. J. Periodontol., 63(6):489-95, 1992.

Marini, M. G.; Greghi, S. L. A.; Passanezi, E. \& Sant'Ana, A. C. P. Gingival recession: prevalence, extension and severity in adults. J. Appl. Oral Sci., 12(3):250-5, 2004.

Matas, F.; Sentís, J. \& Mendieta, C. Ten-year longitudinal study of gingival recession in dentists. J. Clin. Periodontol., 38(2):10918, 2011.

Milinkovic, I.; Aleksic, Z.; Jankovic, S.; Popovic, O.; Bajic, M.; Cakic, S. \& Lekovic, V. Clinical application of autologous fibroblast cell culture in gingival recession treatment. J. Periodontal Res., 50(3):363-70, 2015.

Minaya-Sánchez, M.; Medina-Solís, C. E.; Vallejos-Sánchez, A. A.; Marquez-Corona, M. D.; Pontigo-Loyola, A. P.; Islas-Granilo, H. \& Maupomé, G. Gingival recession and associated factors in a homogeneous Mexican adult male population: a cross-sectional study. Med. Oral Patol. Oral Cir. Bucal, 17(5):e807-13, 2012.

Müller, H. P.; Stardermann, S. \& Heinecke, A. Gingival recession in smokers and non-smokers with minimal periodontal disease. J. Clin. Periodontol., 29(2):129-36, 2002.

Nguyen-Hieu, T.; Ha Thi, B. D.; Do Thu, H. \& Tran Giao, H. Gingival recession associated with predisposing factors in young vietnamese: a pilot study. Oral Health Dent. Manag., 11(3):13444, 2012

Rios, F. S.; Costa, R. S.; Moura, M. S.; Jardim, J. J.; Maltz, M. \& Haas, A. N. Estimates and multivariable risk assessment of gingival recession in the population of adults from Porto Alegre, Brazil. J. Clin. Periodontol., 41(11):1098-107, 2014.

Sarfati, A.; Bourgeois, D.; Katsahian, S.; Mora, F. \& Bouchard, P. Risk assessment for buccal gingival recession defects in an adult population. J. Periodontol., 81(10):1419-25, 2010.

Slots, J. Periodontitis: facts, fallacies and the future. Periodontol. 2000, 75(1):7-23, 2017.

Susin, C.; Haas, A. N.; Oppermann, R. V.; Haugejorden, O. \& Albandar, J. M. Gingival recession: epidemiology and risk indicators in a representative urban Brazilian population. J. Periodontol., 75(10):1377-86, 2004.

Toker, H. \& Ozdemir, H. Gingival recession: epidemiology and risk indicators in a university dental hospital in Turkey. Int. J. Dent. Hyg., 7(2):115-20, 2009.

Vehkalahti, M. Occurrence of gingival recession in adults. J. Periodontol., 60(11):599-603, 1989.

Zucchelli, G. \& Mounssif, I. Periodontal plastic surgery. Periodontol. 2000, 68(1):333-68, 2015.
Corresponding author:

Márcio Eduardo Vieira Falabella

Paulo de Souza Freire St 110/501

Juiz de Fora - MG

Post code 36025350

BRAZIL

E-mail: mevfalabella@hotmail.com

Received: 19-02-2019

Accepted: 17-04-2019 